diffraction in liquids srd geses respectively. Enrolment and offers of papers for these matings should be made before February 15. Geodesy and Geophysics: The Ninth General Assembly of the International Union of Geodesy and Geophysics will take place in Brussels during August 21-September 1. The Assembly will be concerned with geodesy, hydrology, meteorology, physical oceanography, seismology, terrestrial magnetism and electricity and vulcanology. The Royal Society, through its British national committees, is the adhering body for Great Britain to each of the Unions, and available information on these Congresses can be obtained from the assistant secretary of the Royal Society, Burlington House, Piccadilly, London, W.1.

\section{Christmas Lectures}

A SERIEs of three Christmas lectures, specially adapted for a juvenile audience of from twelve to seventeen years of age, will be held in the Royal Photographic Society's House, 16 Princes Gate, London, S.W.7, at 3 p.m. on December 28 and 29, 1950, and January 1, 1951. The lecturers and subjects will be as follows : "Slow-Motion Photography", by Mr. E. W. H. Selwyn; "How a Colour Photograph is Made", by Mr. L. W. Oliver ; and "How to Photograph Buildings", by Miss Margaret F. Harker. Admission will be free but by ticket only, obtainable on application to the Secretary of the Society at the above address.

A series of three Christmas lectures on "Railways : How They are Built and How They Run", for boys primarily between thirteen and seventeen years of age, will be given at the Institution of Civil Engineers, Great George Street, London, S.W.1, at 3 p.m. on December 29, 1950, and January 1 and 3, 1951. These lectures are a repetition of the ones given four years ago, and the speakers will be Mr. Cecil J. Allen, Mr. L. G. B. Rock and Mr. O. S. Nock. Admission will be free but by ticket only, obtainable from the secretary of the Institution at the above address.

\section{The Night Sky in December}

New moon occurs on Dec. 9d. 09h. 28m., U.T., and full moon on Dec. 24d. 10d. $23 \mathrm{~m}$. The following conjunctions with the moon take place: Dec. 4d. 08h., Saturn $3^{\circ}$ N. ; Dec. 10d. 18h., Mercury $3^{\circ}$ N. ; Dec. 12d. 0Ih., Mars $3^{\circ}$ N. ; Dec. 14d. 13h., Jupiter $0.9^{\circ}$ N.; Dec. 31d. 18h., Saturn $4^{\circ}$ N. In addition to these conjunctions with the moon, Mercury is in conjunction with Venus on Dec. 27d. $2 \mathrm{lh}$., Mercury being $2 \cdot 2^{\circ} \mathrm{N}$. Mercury is an evening star, setting thirty-five minutes after the sun on December 1 and an hour and three-quarters after sunset on December 15, but towards the end of the month it draws too close to the sun for favourable observation. Venus is an evening star but is too close to the sun during most of the month for favourable observation ; on December 31 the planet sets at $16 \mathrm{~h} .45 \mathrm{~m}$. and can be seen for a short time in the western sky, stellar magnitude $-3 \cdot 4$ and practically all the illuminated disk being visible. Mars is an evening star and sets about $18 \mathrm{~h} .40 \mathrm{~m}$. throughout the month. Jupiter is an evening star, setting at $22 \mathrm{~h} .25 \mathrm{~m} ., 21 \mathrm{~h} .40 \mathrm{~m}$. and $20 \mathrm{~h} .55 \mathrm{~m}$. on December 1,15 and 31 respectively. Saturn, a morning star, rises at $1 \mathrm{~h} .20 \mathrm{~m}$. on December 1 and at $23 \mathrm{~h}$. $30 \mathrm{~m}$. on December 31 . Only one occultation of a star brighter than magnitude 6 occurs during the month, namely, 27 Taur. $m$, which disappears at $15 \mathrm{~h} .52 \cdot 9 \mathrm{~m}$. as observed at Greenwich. The Geminid meteors are active during the first week of December ; the rediant is close to $\theta$ Geminorum. Winter solstice is on Dec. 22d. 10h.

\section{Announcements}

THE French Ministry of Education has conferred on Miss E. Simpson, assistant secretary of the Society for Visiting Scientists, the honorary rank of Officier d'Académie in recognition of the work which she has done at the Society in the field of AngIo-French scientific co-operation.

Mr. P. H. T. Hartiey, of the Department of Zoological Field Studies, University of Oxford, has been appointed by the Council for the Promotion of Field Studies to be warden of Flatford Mill Field Centre in succession to Dr. E. A. R. Ennion.

DR. JOHN W. TAYLOR has been appointed deputy director-general of the United Nations Educational and Cultural Organization (Unesco) and will take up his duties in Paris on January 1. Dr. Taylor was born in Kentucky in 1905 and has been president of Louisville University since 1947. He was responsible for establishing in Louisville the first U.S. radio station for broadcasting educational and cultural programmes to the general public and to schools.

Dr. W. H. Glanville, director of the Road Research Laboratory (Department of Scientific and Industrial Research) has been elected president of the Institution of Civil Engineers for 1950-51. The following officers have also been elected: S. J. L. Egerton (treasurer) and E. Graham Clark (secretary).

THE Rockefeller Foundation has made available to the University of Cambridge up to 7,000 dollars for the purchase of research equipment and supplies for the Department of Chemistry and up to 5,000 dollars towards the purchase of equipment for research in X-ray crystallography at the Cavendish Laboratory.

The Pharmaceutical Society has received the sum of $£ 1,000$ on trust to establish a Humphreys Jones Scholarship in commemoration of the centenary year of the Liverpool School of Pharmacy and Mr. Humphreys Jones's association with the School for more than forty years.

The Commonwealth Fund is offering three new fellowships open to British professional jourmalists with university or similar qualifications for a stay of about one year in the United States, commencing in September 1951, with the object of studying the factors affecting public opinion and general conditions in the United States. The fellowships are restricted to journalists of $25-35$ years of age, who must be nominated by a responsible newspaper or journal. Applications must be sent in before January 1, 1951, to the Warden of Harkness House, 35 Portman Square, London, W.1.

A very limited number of the complete series of "Excursion Guides" of the Seventh International Botanical Congress (for the complete series of twentyfour, 25 kronor) are available to libraries and botanical institutions until April 1, 1951, after which any copies that might be left over will be made available to individuals. "Communication No. 4" (including the general programme) of the Congress (2 kronor) and also a limited number of copies of "A Short History of Botany in Sweden", by Rob. E. Fries (10 kronor), are generally available. These publications are obtainable from Dr. Ewert Aberg, Office of the Secret. ary-General, c/o Seventh International Botanical Congress, Uppsala 7. 